\title{
THE PAST, PRESENT AND FUTURE OF CLINICAL LEGAL
}

\section{EDUCATION IN POLAND}

Kamil Mamak, Jagiellonian University; The Pontifical University of John Paul II in

Cracow, Poland

Katarzyna Julia Kowalska, University of Warsaw, Poland

Ewelina Milan, Lazarski University, Poland

Paweł Klimek Andrzej Frycz Modrzewski Cracow University, Poland

\begin{abstract}
This paper was written by four lecturers, who are employed at different universities located in Poland's two largest Cities: Warsaw and Cracow. Two of these universities are financed by the government and the other two are financed from students' fees. Our paper critically examines the history of clinical legal education in Poland. It also assesses the economic, legal and social background to the differences and similarities between clinical legal education and legal practice. Furthermore, the paper explains how learning outcomes have led to law clinics becoming a pedagogical and professional treasure trove for individual clinical students and the wider law faculty. The results of this research will demonstrate the invaluable role of learning outcomes to clinical education and professional development. Therefore, the paper will suggest that the methodology of clinical legal education can be employed as a model for Polish higher education.
\end{abstract}

\section{HISTORY OF CLINICAL LEGAL EDUCATION IN POLAND}

From a practical point of view, the oldest profession of legal assistance in Poland is the advocate profession. Its sources go back to the Duchy of Warsaw and the 
Napoleonic Code applicable therein ${ }^{1}$. Therefore, after regaining independence by Poland in 1919, the self-government of advocates was established. The sources of similar analogical profession, the attorney at law profession, date back to the 1960s, when, following the limitation of advocates' privileges, attorneys at law became the only lawyers rendering services to state-owned enterprises. At the beginning of the 1980s, the self-government of attorneys at law was established. Subsequently, privileges of attorneys at law have constantly been extended. Finally, since 2015, attorneys at law and advocates, have been eligible to appear before courts in all cases and differences between these two legal professions are marginal. In addition, the 1990s have seen the emergence of a new profession of the legal adviser. This is not a licensed attorney, yet its position, similarly to that of legal clinics, has been anchored both in the sphere of codified and applied law ${ }^{2}$. From a theoretical point of view, the training of future lawyers in Poland has a much longer tradition, with the first faculty of law established in Cracow in 1364. It took 600 years to combine academic and practical training, as only by $1^{\text {st }}$ October 1997 the first legal clinic at the Jagiellonian University was opened, at the same time being the first legal clinic in Cracow, ${ }^{3}$ and first successful legal clinic in Central and Eastern Europe ${ }^{4}$.

\footnotetext{
${ }^{1}$ P. Skuczyński, Etyka adwokatów i radców prawnych, C.H. Beck 2016, p. 6.

${ }^{2}$ Act of 2 July 2004 on freedom of business activity (consolidated text: Dziennik Ustaw of 2015, item 584, as amended); Judgment of the Constitutional Tribunal of 26 July 2003 SK 22/02 (Dziennik Ustaw of 2003, No. 206, item 2012, v. 1.).

${ }^{3}$ M. Szewczyk, Thoughts on the reform of the teaching of law [in] The Legal Clinic. The Idea, Organization, Methodology, C.H. Beck 2005, p. 17.

${ }^{4}$ E. Rekosh, The development of clinical legal education: a global perspective - international experience, the history of legal clinics [in] The Legal Clinic. The Idea, Organization, Methodology, C.H. Beck 2005, p. 4344 .
} 
However, the very idea of establishing legal clinics in Poland in the faculties of law is much older. The oldest known postulate of introducing clinical training in Poland originates from "Studya i szkice prawne," [Legal studies and sketches] a book published in 1904, in which Szymon Rundstein contained a chapter entitled, "Legal Clinics" ${ }^{5}$. This chapter highlighted the necessity of creating legal clinics in Poland, because he regarded the then forms of training future lawyers as having little practical effect. Rundstein even compared the training of law at the time to teaching amputation using carrots, which took place at certain German medical universities ${ }^{6}$. The model of legal clinic functioning, presented in the said publication, was based on the model being discussed in Germany and did not differ significantly from the one present nowadays in Poland. The publication indicated that:

"In order to prevent the excessive scholastics of lectures, the establishment of so-called legal clinics by universities was proposed. To make it a little bit clearer - the intention was to establish free-of-charge legal assistance offices for poorer people. An office is to be set up at the university under the management of a professor designated by a faculty. Advice is provided by specialists in the presence of students, who, by doing so, may familiarize themselves with life, participate in discussions, answer questions and redraft required acts $[\ldots]^{\prime \prime}$

\footnotetext{
${ }^{5}$ S. Rundstein, Studya i szkice prawne, Lviv 1904, pp. 229-235.

${ }^{6}$ Ibid, p. 232.

${ }^{7}$ Ibid, p. 233.
} 
The core of these assumptions function nowadays: clinics are operated by universities, legal advice is provided for indigent people, students take part in discussions and prepare written opinions and documents and the specialised staff supervise the process. The main difference is that it is not lawyers, but students who provide advice, which is possible due to the fact that the written manner of responses was set as a principle of operations of clinics. Written manner is the inner requirement of operation of a legal clinic which is required by The Legal Clinics Foundation in Poland ${ }^{8}$.

The direct model of functioning of clinics in Poland has not been influenced from Germany, but from the United States. It is connected with, inter alia, Prof. Maria Szewczyk, who, during a scholarship in the United States, familiarised herself with legal clinics operating there. Her keen interest in this idea convinced the authorities of the Faculty of Law and Administration of the Jagiellonian University to create a first legal clinic in Poland, which happened, as indicated above, in 1997 with the help of Halina Nieć. An anecdote, told by Prof. Szewczyk, reveals that the idea of visiting a law clinic in the United States, during her scholarship, was regarded the same as a proposal for visiting a university hospital and for a long time she refrained from it. ${ }^{9}$

\footnotetext{
${ }^{8}$ All clinics in Poland have to meet standards of the polish legal clinics' activity which are required by the Legal Clinics Foundation. One of the standards require that: "legal advice is given in written only". The standards are available in English on the website: http://www.fupp.org.pl/en/legalclinics/standards, access: 10.07.2017.

${ }^{9}$ Cf. T. Betkowska, Swiateczny podarunek, Alma Mater, December 2012 - January 2013, no. 152-153, pp. 12-13.
} 
A year before the opening of the first clinic in Cracow, a conference organised by the European Law Student's Association was held, which related to clinical legal education. It was organised with the assistance of the American Embassy and the Polish bureau of the Organization for Security and Co-operation in Europe. ${ }^{10}$ The aim of this conference was to familiarise polish academicians with the idea of clinical legal education. The second clinic was then established at the University of Warsaw in 1998. Other clinics at the non-public universities, which are in the care of the authors of this publication, were established in 2004 (The Lazarski University Student Legal Clinic, Warsaw) and 2009 (The Student Legal Clinic at the Faculty of Law, Administration and International Relationships of the Andrzej Frycz Modrzewski, Cracow University). ${ }^{11}$

The establishment of the University Legal Clinics Foundation (ULCF) ${ }^{12}$ in 2002 was an important moment in the history of the Polish clinical movement, which had already been postulated during the meeting of legal clinics' representatives in $2001 .{ }^{13}$ The statutory objective of the ULCF is financing legal clinics and carrying out other programs of practical legal education. This includes preparing and standardising the activity of the clinics, initiating works on the organisation and the promotion of projects of legal regulations regarding their activities, in cooperation with legislative, executive and judicial authorities and self-governments of legal professions. The

\footnotetext{
${ }^{10}$ K. Olechowicz, Historia klinik prawa, Klinika 5(9)/2008, p. 20.

${ }^{11}$ For more information please see, http://spp.ka.edu.pl (Last cited 24/05/2017).

${ }^{12}$ For more information please see, http://www.fupp.org.pl/o-fundacji/statut (Last cited 24/05/2017).

${ }^{13}$ F. Czernicki [in:] Studencka poradnia prawna. Idea. Organizacja. Metodologia, Warsaw 2005, p. 238.
} 
ULCF, ran since its creation by Dr. Filip Czernicki, standardises the operations of the legal clinics in Poland, helps to establish new entities and unites the community of the clinical movement in Poland. This is enabled through organising periodical conferences, during which both the students and their mentors have an opportunity to share their experiences and problems that relate to their clinics.

Just after two years of law clinics operating in Poland, it was advocated to regulate their operations and principles of functioning by means of an Act. In addition, it was suggested that a system of free-of-charge legal assistance be established within legal clinics, whereby students could represent their clients in courts. ${ }^{14}$ Until now, the aforesaid recommendations have not been implemented, even though on $5^{\text {th }}$ August 2015, the Free-of-Charge Legal Assistance And Legal Education Act was enacted. ${ }^{15}$ Legal clinics still remain outside the system of free-of-charge legal assistance, and people who provide such advice are not authorised to act on behalf of the clients in courts.

The model of clinical legal education which was implemented in Poland, is a "live client clinic"16, "i.e. the education through work with a real client who has a legal problem, which reflects the work of a legal adviser. Besides, the second important pillar of the practical legal education, which is commonly linked with legal clinics, are

\footnotetext{
${ }^{14} \mathrm{~F}$. Zoll, Introduction to a Draft Act on University Legal Clinic, Klinika. Czasopismo Uniwersyteckiej Poradni Prawnej UJ, no. 1(2)/2000, p. 9.

${ }^{15}$ Ustawa z dnia 5 sierpnia 2015 r. o nieodpłatnej pomocy prawnej oraz edukacji prawnej, Dziennik Ustaw of 2015, item 1255, as amended.

${ }^{16}$ M. Szewczyk, Idea uniwersyteckich poradni prawnych, Klinika. Czasopismo Uniwersyteckiej Poradni Prawnej UJ, no. 1/1999, p. 15.
} 
street law-style programs - carried out on a large scale at the Lazarski University. It is worth noticing that Poland was the third country in which the idea of street law in legal education was introduced, thanks to Prof. Monika Płatek from the University of Warsaw" 17

An important aspect which connects the Polish clinical movement is publications, which are generated as a result of the operations conducted in legal clinics. One of the experience exchange forums is the magazine Klinika, initially issued by the Jagiellonian University, and later by the ULCF, in cooperation with C.H. Beck publishing company ${ }^{18}$. The editorial information of the first issue from 1999, stated that the magazine was supposed to be, "a forum of exchanging experiences regarding the operation of particular clinics. It was supposed to present (...) not only "the clinical education method", but also all innovative educational programs." ${ }^{19}$ It seems that the assumptions of the authors of the first issue remain valid now - merely two decades after writing them down. Indeed, it is a magazine which aims to improve the operation of the legal clinics in Poland by exchanging experiences. In regards to the publications, it is worth noting that the ULCF, in cooperation with C.H. Beck, managed to issue a

\footnotetext{
${ }_{17}$ A. Światłowski, Place of "Clinic Programmes" of the Street Lawtyfe in Legal Clinic Education in Poland, Klinika. Czasopismo Uniwersyteckiej Poradni Prawnej UJ, no. 3/2000, p. 20.

18 "Klinika. Czasopismo Uniwersyteckiej Poradni Prawnej UJ" issue 1/1999.

${ }^{19}$ Od redakcji [in:] Klinika. Czasopismo Uniwersyteckiej Poradni Prawnej UJ, no. 1/1999, p. 7.
} 
series of textbooks, which help to improve the workshop skills of mentors ${ }^{20}$ and students ${ }^{21}$.

The short, review of the history of the Polish clinical movement seems to confirm the opinion of Prof. Eleonora Zielińska discussed previously, that the commencement of clinical education within law faculties is regarded as the beginning of a new era in educating lawyers. ${ }^{22}$ In addition, nowadays it is hard to imagine a law faculty lacking this kind of education, further proven by the number of legal clinics in operation currently in Poland there are 25 law clinics in 16 cities. ${ }^{23}$

\section{LEGAL, ECONOMIC, POLITICAL AND SOCIAL DENOTATION OF \\ CLINICAL LEGAL EDUCATION IN POLAND}

Twenty years of the evolution of clinical education has had a bearing on Polish codified and applied law. ${ }^{24}$ Therefore, the current Polish clinical movement is worth analysing in terms of economic, social, political and legal issues. The objective of this analysis is to highlight the perspectives of the development of the clinical movement, in the background of the parallel expanding conglomerate of Polish liberal legal

\footnotetext{
${ }^{20}$ E.g. I. Kraśnicka [ed.], Metodologia pracy w SPP, Warsaw 2009, B. Namysłowska-Gabrysiak [ed.], Studencka poradnia prawna. Podręcznik dla opiekunów, Warsaw 2009.

${ }^{21}$ E.g. B. Namysłowska-Gabrysiak [ed.], Studencka poradnia prawna. Kompendium dla studentów, Warsaw 2008.

22 E. Zielińska [in:] Studencka poradnia prawna. Idea. Organizacja. Metodologia, Warsaw 2005, p. XVI.

${ }^{23}$ Data for 2015/2016, the report entitled "Studenckie Poradnie Prawne. Podsumowanie działalności za rok akademicki 2015/2016". http://www.fupp.org.pl/kliniki-prawa/publikacje/raporty (Last cited 24/05/2017).

${ }^{24}$ Judgment of the Constitutional Tribunal of 26 July 2003 SK 22/02 (Dziennik Ustaw of 2003, No. 206, item 2012, v. 1.).
} 
professions, the centralising market of fee-based and free-of-charge legal services and the generational conflict, which is a natural phenomenon in a stable country. ${ }^{25}$

The multidimensional analysis is always subject to a degree of subjectivity. ${ }^{26}$ Therefore, it must be stated that the author of this section is a 31-year-old male, a legal adviser, trainee attorney at law and an academic teacher. He provides legal assistance for both fee-based and free-of-charge legal services. In addition, he practises both as a tax law specialist and as a lawyer in general. His geographical area of practice embraces the most urbanised part of Poland, i.e. the Upper Silesia and the Cracow Agglomeration, wherein area of $17,662.5$ square kilometres is inhabited by circa 5 million people, therefore almost two times more than in the Warsaw Agglomeration ${ }^{27}$. However, this area does not have a function of a capital city, but its role is just as important, because it serves more like the largest capital city's background. As a consequence, the biggest law firms (Dentons, Sołtysiński Kawecki \& Szlęzak, Domański Zakrzewski Palinka, CMS, Deloitte Legal) ${ }^{28}$ and the so-called "big four" tax advisory companies (Deloitte, KPMG, PwC, EY), ${ }^{29}$ with their registered offices in Warsaw, focus on this area to a lesser extent. Moreover, this area lacks the autonomy,

\footnotetext{
${ }^{25}$ R. Prasad, Generation gap. A sociological study of Intergenerational conflicts, New Dehli 1992, p. 191.

26 A. Gelman, C. Hennig, Beyond Subjective and Objective in Statistics, 2015, p. 9. http://www.stat.columbia.edu/ gelman/research/published/gelman_hennig_full_discussion.pdf (Last cited 02/01/2018).

${ }^{27}$ Central Statistical Office, Size and Structure of Population and Vital Statistics by Territorial Division in 2010, 2011, pp. 13-14. https://web.archive.org/web/20111127094758/http://www.stat.gov.pl/gus/5840_655_PLK_HTML.htm (Last cited 02/01/2018).

28 For more information please see, http://www.rp.pl/Rankingi/304209944-Ranking-KancelariiPrawniczych-Rzeczpospolitej-2017---wyniki.html (Last cited 20/05/2017).

${ }^{29}$ For more information please see, http://www.rp.pl/Rankingi/306219998-Ranking-Firm-DoradztwaPodatkowego-2016-wybralismy-najlepszych. html (Last cited 20/05/2017).
} 
unified local self-government, one unified court of appeal and tax chamber, a result of which the law firms are run by sole practitioners more frequently and the prices of legal services are lower than in the capital city.

Before an analysis of the centralisation of the market of fee-based and free-ofcharge legal services is made, it is worth discussing the conglomerate of the Polish liberal legal professions. Currently, alongside the advocates, attorneys at law and legal advisers, legal services are being rendered as part of quasi-legal professions, such as a tax adviser, a chartered accountant and a patent agent ${ }^{30}$. In addition, many young lawyers decide to specialise in a particular field of law. Trainee advocates and trainee attorneys at law are entitled to represent the clients in courts, from the completion of the sixth month of traineeship, which lasts 45 months in total ${ }^{31}$. As a result, we can talk about the conglomerate and not the orderly system of the Polish liberal legal professions. This conglomerate is full of paradoxes, such as:

- employing attorneys at law and advocates in the offices of legal advisers, due to the lack of restrictions for the latter to advertise their services

- running law offices independently by trainee attorneys at law and trainee advocates, who, at the same time, act as legal advisers

\footnotetext{
${ }^{30}$ Act of 5 July 1996 on tax advisory services (consolidated text: Dziennik Ustaw of 2016, item 794, as amended), Act of 7 May 2009 on chartered accountants and their self-government, entities authorized to audit financial statements and on public supervision (consolidated text: Dziennik Ustaw of 2016, item 1000, as amended), Act of 11 April 2001 on patent agents (consolidated text: Dziennik Ustaw of 2016, item 221, as amended).

${ }^{31}$ Act of 26 May 1982 - Law on advocacy (consolidated text: Dziennik Ustaw of 2016, item 1999, as amended), Act of 6 July 1982 on attorneys at law (consolidated text: Dziennik Ustaw of 2016, item 233, as amended).
} 
- rendering tax law services by trainee attorneys at law and trainee advocates, who, since the completion of the sixth month of traineeship, have entitlements equal to those of tax advisers

- a possibility to account fees for attorney at law traineeship as tax deductible costs, which is not applicable for fees for advocates' traineeship.

To conclude, there are two legal professions self-governments and internal regulators (of advocates and attorneys at law) and three quasi-legal professions selfgovernments and internal regulators, which, from the point of view of the market, restrict the powers of unlicensed legal advisers to render legal services. Moreover, these self-governments are dominated by the older generation. ${ }^{32}$ Nevertheless, the younger generation still enters the legal services market, carefully omitting the advertisement ban and making use of expanded powers of trainee advocates and trainee attorneys at law. As a result, the diversified conglomerate of liberal legal professions originated, in which the free market crowds out the licensing.

At the same time, legal services are rendered by law students, who do it without remuneration employed in law firms, or free of charge in legal clinics under the

\footnotetext{
32 The average age of members of the Presidium of the Polish Bar Council (Prezydium Naczelnej Rady Adwokackiej) and the Presidium of the National Council of Attorneys at Law (Prezydium Krajowej Rady Radców Prawnych) is 57 years. http://www.nra.pl/nra.php?id=329 (Last cited 03/01/2018), http://kirp.pl/o-samorzadzie/organy-ustawowe-i-regulaminowe/prezydium-krajowej-rady-radcowprawnych/ (Last cited 03/01/2018).
} 
guidance of academic teachers. ${ }^{33}$ During 2015 and 2016, however, a parallel state system of free-of-charge legal assistance was established. ${ }^{34}$ Consequently, the younger generation of lawyers on a wider scale has been grouping in non-governmental organisations (NGOs), which, on the basis of the contests organised by local selfgovernments, constitute 50 per cent of 1,500 free-of-charge legal assistance points (FLAP). ${ }^{35}$ The remaining 50 per cent of the FLAP are those operated by legal professions self-governments of advocates and attorneys at law. Moreover, on the estimation based on the questionnaires, it stems that 40 per cent of lawyers employed in the FLAP and recruited by NGOs are graduates of the legal clinics. ${ }^{36}$

As a result, during 2015 and 2016 the quasi-regulated market of free-of-charge legal services began in Poland. Nonetheless, legal services are concurrently rendered by the offices of the Members of Parliament and the Senatorial offices, as well as by small law firms. These law firms act due to economic interests, and treat a free-ofcharge service as a service aimed at attracting clients.

That said, in Poland, free-of-charge legal services exist in parallel to the corporations of liberal legal professions. In the former, the clinical legal education method was applied only with respect to part of the younger generation of lawyers ${ }^{37}$.

\footnotetext{
${ }^{33}$ Currently, the University Legal Clinics Foundation coordinates 25 legal clinics, in which circa 2,000 students and 300 lawyers operate. http://www.fupp.org.pl/kliniki-prawa/publikacje/raporty (Last cited 20/05/2017).

${ }^{34}$ Act of 5 August 2015 on the free-of-charge legal assistance and legal education (Dziennik Ustaw of 2015, item 1255, as amended).

${ }^{35}$ Dogma Association in Mikołów, running 33 FLAP that hire 52 lawyers (mainly in the Upper Silesia), can serve as an example.

${ }^{36}$ The questionnaire conducted among the lawyers employed by the Dogma Association in Mikołów on 9 April 2017 thanks to the courtesy of President Iwona Serbeńska.

${ }^{37}$ A. Zoll [in:] Studencka poradnia prawna. Idea. Organizacja. Metodologia, Warsaw 2005, p. XV.
} 
Nevertheless, in the light of the increased competition, clinical legal education is a method that allows adopting models of responsibility for the client and strengthens the quality of the services rendered. This method shall have a wider application in the process of the education of aspiring lawyers and its use by the older generation of practice teachers ${ }^{38}$ and NGOs, so that sole practitioners can develop the know-how worked throughout the last 20 years by ULCF.

The brands of the biggest and most renowned law firms indicate the increasing involvement in the English, Scottish, Canadian, American and Dutch capital, ${ }^{39}$ although the Polish market of free-of-charge legal services is certainly not as dominated by the so-called "big four" as the market of fee-based tax advisory ${ }^{40}$. However, it cannot be disregarded that the fastest growing law firm in Poland is Deloitte Legal, with KPMG D. Dobkowski, PwC Legal and EY Law also operating in the Polish fee-based market of legal services. ${ }^{41}$ In Poland it is still not customary to establish branches providing free-of-charge legal assistance in the biggest law firms in order to strengthen their image. It is even more important as the FLAP are mainly

\footnotetext{
${ }^{38}$ The teachers, who teach practical subjects during academic studies and during advocates and attorneys at law apprenticeships, such as civil or criminal procedure, so students and trainee: advocates and attorneys at law shouldn't take a part in so many lectures and solve theoretical cases, but they should write more documents, such as writs or appeals and take a part in real cases, at least they should simulate.

39 http://www.rp.pl/Rankingi/304209944-Ranking-Kancelarii-Prawniczych-Rzeczpospolitej-2017--wyniki.html (Last cited 20/05/2017).

40 http://www.rp.pl/Rankingi/306219998-Ranking-Firm-Doradztwa-Podatkowego-2016-wybralismynajlepszych. html (Last cited 20/05/2017).

${ }_{41}$ http://www.rp.pl/Rankingi/304209944-Ranking-Kancelarii-Prawniczych-Rzeczpospolitej-2017--wyniki.html (Last cited 20/05/2017).
} 
located outside the area of the capital city and the public money aimed at financing the FLAP are distributed on the basis of tenders organised by local self-governments ${ }^{42}$.

There are tax solutions that could boost the free-of-charge legal assistance activities of the biggest law firms. Such solutions encompass the possibility to reduce the tax basis of the Personal Income Tax (PIT) and Corporation Income Tax (CIT) by the donations granted to NGOs and the possibility to transfer $1 \%$ of the PIT to the latter. ${ }^{43}$ Such solutions already exist in the tax systems of other highly developed countries. ${ }^{44}$ Moreover, the corporate structures coming from the highly developed countries such as the United States, Canada, Australia, Japan, Germany, France, the Netherlands and the United Kingdom, are, as a rule, comprised of the so-called corporate foundations, such as the Ronald McDonald House Charities ${ }^{45}$. Therefore, it is likely to expect that the "big four" will enter the Polish market of free-of-charge legal services in the coming years.

Nevertheless, if such action is to have only the image reasoning behind it, it will be similar to French-German Opel solution which manufactures cars in the Polish Upper Silesia and exports them to the United Kingdom under the Vauxhall brand. In essence, rendering the high quality free-of-charge legal services comes down to the

\footnotetext{
${ }^{42}$ Article 11 paragraph 1 and 2 of The free-of-charge legal assistance and legal education Act 2015.

${ }^{43}$ Act of 26 July 1991 on the personal income tax (consolidated text: Dziennik Ustaw of 2016, item 2032, as amended); Act of 15 February 1992 on the corporate income tax (consolidated text: Dziennik Ustaw of 2016, item 1888, as amended)

${ }_{44}$ P. Klimek, Elementy zapobiegające nadmiernym odliczeniom darowizn na gruncie podatków dochodowych, [in:] I. Czaja-Hliniak (ed.), Nauka prawa finansowego po I dekadzie XXI wieku - Księga Pamiątkowa dedykowana Profesorowi Apoloniuszowi Kosteckiemu, Cracow 2012, pp. 449-463

${ }^{45} \mathrm{P}$. Klimek, Możliwość odliczenia 1\% podatku dochodowego na rzecz fundacji korporacyjnych $i$ społecznych, Edukacja Prawnicza, no. 5 (125); Extra supplement: Klinika - Czasopismo Fundacji Uniwersyteckich Poradni Prawnych, no. 10 (14), pp. 21-23.
} 
models adopted in clinical legal education and the responsibility for the client's problem. In the absence of such models, the authority of the clinical movement can collapse in the same manner as the authority of the biggest law firm, which lobbies the government authorities in an unreasonable manner. ${ }^{46}$

Therefore, the key challenge for the Polish clinical movement is to educate by disseminating good models, based on practical abilities, such as regularity of conduct, revision of the most essential newly issued legal acts and court judgments and interviewing a client in a reliable and skillful manner in order to determine the nature of the problem.Only then will assistance which is provided to the most socially disadvantageous people be effective, irrespective of whether it will be provided by a student, legal adviser, advocate, attorney at law or tax adviser, acting individually or in a renowned law firm.

To sum up, in order to develop clinical education throughout all law schools in Poland, the clinical movement shall:

- from the economic point of view: take into account the phenomenon of increasing importance of the biggest law firms, which may be interested in the market of free-of-charge legal services

- from the social point of view: remain resilient to the intensifying divisions between lawyers providing legal assistance

\footnotetext{
${ }^{46}$ http://www.batory.org.pl/upload/files/Programy\%20operacyjne/Odpowiedzialne\%20Panstwo/Lobb ing_Raport. pdf (Last cited 20/08/2017)
} 
- from the political and legal point of view: react to decisions which are contrary to pro bono interests, by lobbying in order to guarantee that legal clinics have the same status of the FLAP and are financed from the public resources. However, if this status and financing proves to be too excessive, then the clinical movement shall focus on the cooperation with NGOs, as the estimates highlighted in various questionnaires indicate that in 2016 the FLAP refused the assistance in 68,300 cases, including assistance to the following persons: poor, disabled, unemployed, those afflicted with alcoholism, single parents or non-nationals. ${ }^{47}$ Therefore, there is still a considerable number of people who require legal assistance. However, the large amount of NGOs can be developed, thanks to younger generation of lawyers educated with clinical legal education method. NGOs do not possess as advanced legal knowledge and skills as the clinical movement can provide.

\section{THE LEGAL CLINIC - A TREASURE TROVE OF LEARNING OUTCOMES}

Since, the 1970's the European Union has sought to harmonize and improve the educational systems of member states through the adoption of a centrally agreed set

\footnotetext{
${ }^{47}$ The questionnaire conducted among the lawyers employed by the Dogma Association in Mikołów on 9 April 2017 thanks to the courtesy of President Iwona Serbeńska.
} 
of frameworks and policies known as the Bologna process. ${ }^{48}$ One of the most important aspect of this process was the establishment of learning outcomes that were then incorporated into the parliamentary legislation that regulates the educational practices of member states. ${ }^{49}$ In Poland, the 2005 Higher Education Act incorporated the standardised qualification framework into law. ${ }^{50}$ This was augmented by the 2011 Education Act which requires all elements of syllabi to be matched to specified learning outcomes. ${ }^{51}$ It is hoped that this will led to a shift from subject/teacher based pedagogy to learning that is more focused on the needs of the learner.

These outcomes are divided into three categories: knowledge, skills and social competences that are gained in the course of education by a learner: ${ }^{52}$

a) knowledge - "the outcome of the assimilation of information through learning. Knowledge is the body of facts, principles, theories and practices that is related to a field of work or study. In the context

\footnotetext{
${ }^{48} \mathrm{http} / / / \mathrm{www}$.pilnet.org/public-interest-law-resources/25-clinical-legal-education-and-the-bolognaprocess.html

49 "The shift to learning outcomes. Conceptual political and practical developments in Europe", CEDEFOP 2008

${ }^{50}$ Law on higher education (pdf, Dziennik Ustaw - Official Journal of Laws of 27 July 2005, No.164, item 1365, as amended; art. 9 ust. 1. punkt. 2). http://en.uw.edu.pl/wpcontent/uploads/2014/06/law_on_higher_education.pdf (Last cited ?).

${ }^{51}$ Rozporządzenie Ministra nauki i szkolnictwa wyższego z dnia 2 listopada 2011 r. w sprawie Krajowych Ram Kwalifikacji dla Szkolnictwa Wyższego, Dz.U. 2011 nr 253 poz. 1521.

${ }^{52}$ For more information please see, http://www.nauka.gov.pl/krajowe-ramy-kwalifikacji/ (Last cited on 26/05/2017).
} 
of the European Qualifications Framework, ${ }^{53}$ knowledge is described as theoretical and/or factual" 54

b) skills - "the ability to apply knowledge and use know-how to complete tasks and solve problems. In the context of the European Qualifications Framework, skills are described as cognitive (involving the use of logical, intuitive and creative thinking) or practical (involving manual dexterity and the use of methods, materials, tools and instruments)" 55

c) competence - "the proven ability to use knowledge, skills and personal, social and/or methodological abilities, in work or study situations and in professional and personal development". In the context of the European Qualifications Framework, competence is described in terms of responsibility and autonomy." 56

The previous section discussed developments in legal education and the practice of working with real clients in Polish legal clinics. This has enabled learning outcomes

\footnotetext{
${ }^{53}$ The European Qualifications Framework (EQF) is "a reference tool to compare the qualification levels of the different qualifications systems and to promote both lifelong learning and equal opportunities in the knowledge-based society, as well as the further integration of the European labor market, while respecting the rich diversity of national education systems".

${ }^{54}$ Annex I for Recommendation of the European Parliament and of the Council of 23 April 2008 on the establishment of the European Qualifications Framework for lifelong learning, (Official Journal 111/1 of 6.5.2008).

https://eurlex.europa.eu/legalcontent/EN/TXT/HTML/?uri=CELEX:32008H0506(01)\&from=EN (Last cited?).

${ }^{55}$ Ibid.

${ }^{56}$ Ibid.
} 
to be introduced to a greater extent than other parts of polish Higher Education. The ultimate aim of the education process of a legal clinic is to develop a student's social competences and skills, which are based on knowledge of the law, that the student can use to feed into their future learning. An equally important element of education in Polish clinics is that, underlying all three components (knowledge, social competences and skills) stands a human being (the student) living in a particular economic, political, legal and cultural system, who throughout the entire education process is confronted with ethical dilemmas.

In the light of the considerations set forth in the previous section of this publication, the legal clinic may be perceived as the place where both the student and the teacher (mentor) are effectively educated. The authors of this article understand the aims of effective education are the following:

a) preparing students for professional practice and provide effective assistance to the clients;

b) developing the students' sense of taking responsible for problems;

c) assisting the student in obtaining such learning outcomes that allows them to understand what has been learnt.

This understanding of the educational process allows educators to fully implement in the clinics the requirements of the Bologna Process, together with its flagship "learning outcomes." The positive effects of this have been registered by both the students and the university senior management. There is a common belief among 
students that law clinics are ideal places where, under the vigilant eye of their mentors, one can verify their knowledge, skills and competences required for the practical exercise of the profession. ${ }^{57}$ This positive effect has been noted by the senior management of the authors' universities, as it is seen as a demonstration of the implementation of the aims envisaged by the Bologna Process and successive ministers of education.

At the same time, what has been emphasised by the authors in the previous sections is that the notion of "effective education" cannot be considered in isolation from the economic, legal, social and cultural situation in which the students and their mentors function. Pedagogical practices in Poland are often centred on more traditional knowledge or teacher centred methods and this has proved to be a barrier to a more fuller implementation of the learner centred approaches based on learning outcomes. In addition, many students focus on the attaining of a qualification or certificate as a means in itself rather than focusing on developing their skills and knowledge.

In contrast to these more traditional teacher/knowledge centred pedagogical practices favoured in most of Polish higher education, legal clinics have embraced more learner centred methods. The considerable autonomy enjoyed by Polish legal clinics has allowed them to employ a number of fresh approaches to clinical education, comprising of diverse approaches to the students' education, applied educational

\footnotetext{
${ }^{57}$ In press R. Dunn 'The Knowledge, skills and attributes considered necessary to start day one training competently and whether live client clinics develop them' (2018)
} 
methods and open-mindedness of the academic teachers. Above all, such clinics are treasure troves of knowledge, in regards to the educational methods and developing learning outcomes, which are not merely a wish list. It should be noted that the learning outcomes are most effective when they are transparent and measurable, clearly defined and able to be accomplished by the students. Transparency enables the student and the clinician to clearly understand what learning needs to be achieved, while measurability means it is clear to what extent the student has achieve their goal. It also can provide a robust framework for assessing and assessment. In addition these elements can provide the basis for a dialogic relationship between clinicians and students. Beyond the university environment potential employers could use these transparent and measurable learning outcomes to select applicants.

This could be accomplished by the legal clinic emphasising to students the links between the syllabus, assessment criteria and its expectation of students. However, more work needs to be done in this area. The classes in Polish legal clinics are planned in such a manner that the outcomes can contribute to the achievement of the educational goals set forth in Bloom's taxonomy (see Figure 1), displayed below, ${ }^{58}$ which constitutes a hierarchy of increasingly complex processes. These processes, in the context of clinical legal education, are aimed at preparing students both in the

\footnotetext{
${ }^{58}$ Bloom, B. S. (ed.). Taxonomy of Educational Objectives. Vol. 1: Cognitive Domain. New York: McKay, 1956.
} 
course of short seminars and training sessions, as well as for producing opinions or judicial documents. ${ }^{59}$

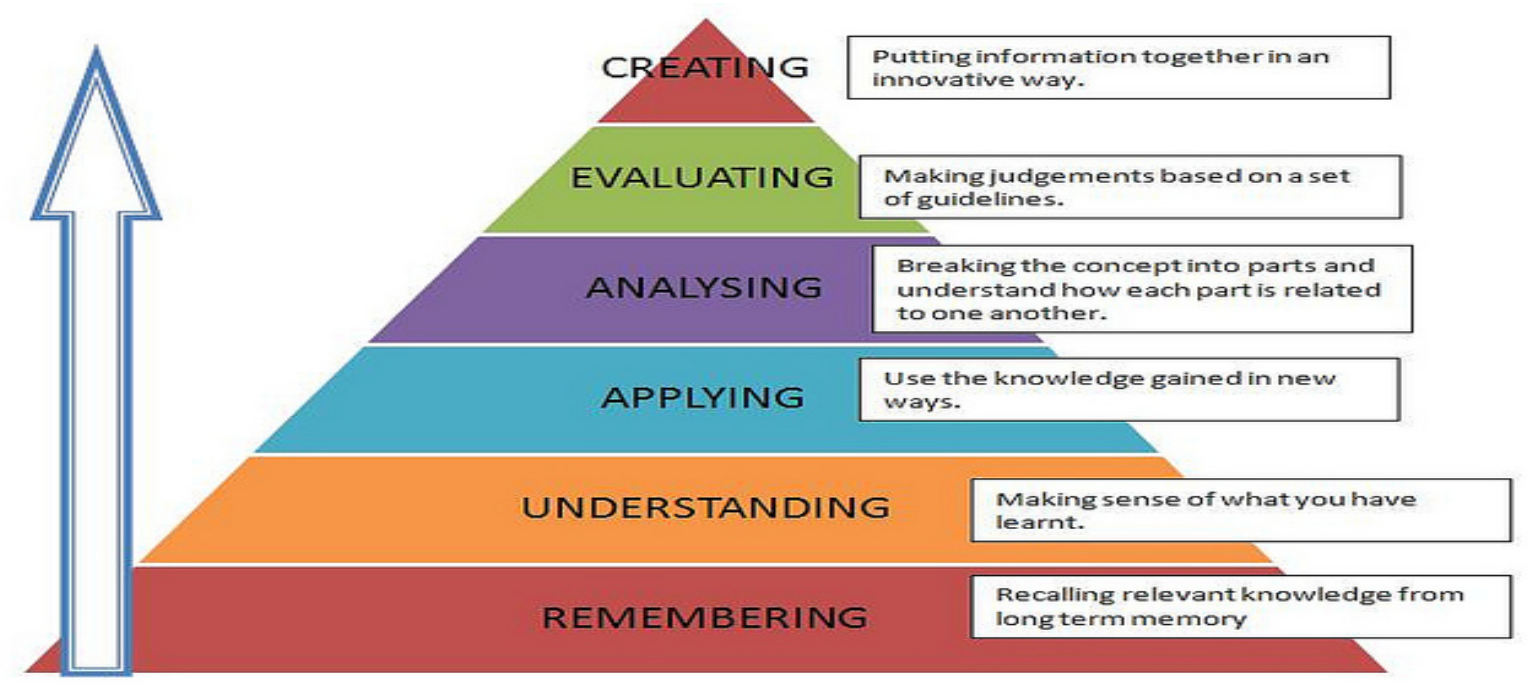

\section{Figure 1 - Bloom's Taxonomy of Learning ${ }^{60}$}

At the top of his taxonomy, Bloom placed "creating," which can be understood as the ability to design, construct, use and create something new. Creating, being the final learning outcome, ideally fits into the education process in Polish legal clinics where the final learning outcome for the student is the preparation of an opinion or a writ. Therefore, the outcome of the student's work with each client is creating something new and, in order to accomplish it, the student has to apply social skills competences based on the gained knowledge such as successfully interaction with clients, fellow students and mentors. The knowledge which the student has,

\footnotetext{
59 Tyler, Jo A., and Faith Mullen. "Telling tales in school: storytelling for self-reflection and pedagogical improvement in clinical legal education." Clinical L. Rev. 18 (2011): 283.

${ }^{60} \mathrm{https}: / /$ www.google.pl/search?q=bloom+taksonomii\&source=lnms\&tbm=isch\&sa=X\&ved=0ahUKEwi Rkdewp4_UAhXHSBQKHbMhD3AQ_AUICCgD\&biw=774\&bih=373\&dpr=2.4\#imgrc=AO5AHslFk6Q bEM (Last cited 28/05/2017).
} 
understood, applied, analysed and assessed is to meet the challenge of providing legal assistance.

We strongly believe that working with clients, rather than published materials, gives students valuable experience of the complexity of real life legal practice. This can furnish students with a sense of the enormous responsibility for providing effective assistance to clients and the potentially far reaching consequences of their actions. Working with clients requires the tutor to introduce additional learning outcomes, which, without the client's participation, would not be possible. Soren Kierkeegard argues that having social skills are more important than an understanding of theory or pedagogy when seeking to relate to another person in a subject manner. ${ }^{61}$ As clinicians we can help students develop these personal competences through their practice in law clinics.

The Polish qualifications framework can be adapted by institutions to better meet their particular needs. ${ }^{62}$ For example at Lazarski University, the Faculty of Law and Administration Directional learning outcomes (see Table 1 below) defines 11 desirable skills. This means that even if the student does not master everything, he will still

\footnotetext{
${ }^{61}$ S. Wasiołka, the presentation Narzędzia informatyczne w pracy dyrektora szkoły, Poznań 27.11. 2013 https://www.slideshare.net/Jozefzbazin/prezentacja-dyrektorzy-pozna ${ }^{62}$ J. Kudła, M. Stachowiak - Kudła, A. Figurski Quality of Teaching and Research in Public Higher Education in Poland: Relationship with Financial Indicators and Efficiency "Journal of Management and Business Administration. Central Europe"

Vol. 24, No. 4/2016, p. 88-108 0
} 
graduate. However, the level of their mastery of the skills is partly reflected in their final grade. ${ }^{63}$

\section{Table 1 - Faculty of Law and Administration Lazarski University Directional learning outcomes: Law}

\begin{tabular}{|c|c|}
\hline K_U01 & $\begin{array}{l}\text { 1. is able to properly interpret and explain the importance of particular legal norms and } \\
\text { mutual relations between these norms within different branches of law }\end{array}$ \\
\hline K_U02 & $\begin{array}{l}\text { 2. is able to use the acquired theoretical knowledge of different branches of law to describe } \\
\text { and analyse the reasons and the course of processes of amending law and is able to } \\
\text { formulate own opinions and select critical data and methods of analysis that are used in } \\
\text { legal studies }\end{array}$ \\
\hline K_U03 & $\begin{array}{l}\text { 3. is able to forecast changes in legal regulations with the use of sophisticated research } \\
\text { methods and tools typical of legal studies }\end{array}$ \\
\hline K_U04 & $\begin{array}{l}\text { 4. is efficient in dealing with the Polish legal system; uses adequate norms and legal rules } \\
\text { in order to solve particular problems; has good skills in solving complicated legal problems } \\
\text { in specified branches of law in accordance with subjects selected on his/her own }\end{array}$ \\
\hline K_U05 & $\begin{array}{l}\text { 5. has good skills in using the acquired knowledge to present own opinions, doubts and } \\
\text { suggestions as well as supporting them with elaborated arguments and following ethical } \\
\text { principles }\end{array}$ \\
\hline K_U06 & $\begin{array}{l}\text { 6. has a skill in proposing particular solutions of legal problems on his/her own and in } \\
\text { carrying out a procedure of decision-making in this area }\end{array}$ \\
\hline K_U07 & 7. has a skill in forecasting consequences of the planned actions in different branches of law \\
\hline K_U08 & $\begin{array}{l}\text { 8. has well-developed research skills; formulates issues, selects adequate research methods, } \\
\text { techniques and tools that are used in legal studies; develops, presents and interprets } \\
\text { research findings; is able to draw adequate conclusions and to indicate directions of further } \\
\text { research within the selected branches of law }\end{array}$ \\
\hline K_U09 & $\begin{array}{l}\text { 9. has a good skill in drawing up basic procedural documents regarding legal issues, } \\
\text { preparing written analyses of selected legal issues with a proposal of adequate solutions } \\
\text { with the use of the acquired theoretical knowledge }\end{array}$ \\
\hline
\end{tabular}

\footnotetext{
${ }^{63}$ In the Polish education system, each student after completing a course receives a grade on the scale of $1-5$, with 1 being the lowest grade and 5 the highest. Passing grades are from 3 to 5 . However, with regards to ECTS points all passing grades are awarded the same number of ECTS points. Therefore, a clear description of the attainment of the desirable skills by a student is important for potential employers as a way to differentiate between candidates.
} 


\begin{tabular}{|l|l|}
\hline K_U10 & $\begin{array}{l}\text { 10. has a good skill in preparing speeches directly connected with legal matters and } \\
\text { regarding issues on the borderline between law and other sciences with the use of the } \\
\text { acquired theoretical knowledge }\end{array}$ \\
\hline K_U11 & $\begin{array}{l}\text { 11. has linguistic skills in accordance with the requirements specified for the B2 level of } \\
\text { Common European Framework of Reference for Languages }\end{array}$ \\
\hline
\end{tabular}

The analysis of the survey outcomes lets us conclude that work within the clinic allows the students to gain and preserve the skills marked with symbols K_U01, K_U04, K_U05, K_U06 and K_U09. The most important out of the skills appears to be the one marked with symbol K_U09, i.e. "has a good skill in drawing up basic procedural documents regarding legal issues, preparing written analyses of selected legal issues with a proposal of adequate solutions with the use of the acquired theoretical knowledge" ${ }^{64 . "}$

This ability is of particular importance, as the preparation of even a simple writ in the Polish legal system requires an in-depth analysis of a problem, because in the majority of cases a writ constitutes a written analysis of the problem (e.g. in the case of a statement of claim or complaints) fulfilling the requirements of the procedural law. Furthermore, it is essential to remember that errors or formal shortcomings in pleas cannot be often corrected or supplemented during Polish court proceedings. Therefore, any erroneous analysis of the problem may result in the erroneous preparation of court documents without the possibility of corrections, which may result e.g. in the exhaustion of the access to court in seeking remedies.

\footnotetext{
${ }^{64}$ https://www.lazarski.pl/fileadmin/user_upload/dokumenty/wydzial-prawajakosc/Efekty_ksztalcenia_Prawo.pdf
} 
Of course, let us not forget the fact that establishing a successful Legal Clinic would not be possible without the support of the clinical teachers, who are well aware that only through the use of well-selected educational methods may the desired learning outcomes be achieved. Therefore, in the context of the changes to the manner of teaching expected to be implemented in Polish higher education, law clinics become not only a place for creating concepts on dealing with such changes, but also a resource bank of experience and knowledge for practitioners, who are able to cope with new challenges. To sum up, the key to the success of Polish legal clinics lies in the structure and implementation of these educational programs. Students can achieve the learning outcomes, allowing them to become creative, in line with Bloom's taxonomy. Thus the creation of original legal opinions by the students from their interaction with clients, examination of documents and knowledge of the law is the most tangible benefit of clinical education. In addition, teachers work in a group comprising of more openminded people who are well prepared to exercise their profession. This is undoubtedly one of the key pillars that support the successes of the Polish legal clinics, particularly with regard to the implementation of educational outcomes.

Thus Polish legal clinics are good places to help students understand the relationship between theory and practice, ${ }^{65}$ as, stated in the well-known Arabic proverb, "A man who learns and learns, yet fails to apply the knowledge that has been learnt, is like a farmer who sows and sows, yet fails to harvest crops from a field."

${ }^{65}$ Grimes, Richard. "Learning law by doing law in the UK." International Journal of Clinical Legal Education 1 (2014): 54-57. 
Therefore, legal clinics are places where the change to the Polish legal education culture can originate.

\section{METHODOLOGY OF CLINICAL LEGAL EDUCATION - THE FUTURE OF POLISH HIGHER EDUCATION}

All educational methods, used when working with a group, shall be adjusted to the needs and abilities of the learners, as well as focused on the outcome of this specific interaction between the lecturers and the learners. Only ensuring that the academic courses are based on such model of thinking about the courses with the students allows teaching and building relationships in an effective manner, making a good cooperation throughout an academic year possible.

The cooperation developed with the students is extremely important, in particular in clinical education, as this relationship directly impacts the fulfilment and implementation of the clinical education standards, ${ }^{66}$ which apply to all university legal clinics, forming part of the ULCF's network. ${ }^{67}$

The clinical courses, due to a smaller number of students in the groups and a closer working relationship between the lecturers and the students (which is necessary for working on documents for clients or for workshops during which each of group member should have emotional comfort to present their opinion) could serve as a

\footnotetext{
${ }^{66} \mathrm{I}$ hereby refer to the extended standard, which relates to ensuring by a legal clinic of the supervision of the didactic staff over the students (standard no. 2 no. 9/2014 of the resolution of the University Legal Clinics Foundation dated 08 March 2014, http://www.fupp.org.pl/kliniki-prawa/standardy (Last cited $18 / 05 / 2017)$.

${ }^{67}$ Please read more on the activities of this foundation: http:// www.fupp.org.pl (Last cited 18/05/2017).
} 
model for all university courses. ${ }^{68}$ In Poland the courses at higher educational institutions may adopt a form of, inter alia: lectures, workshops, seminars or conservatories, all of which have one objective: to transfer knowledge. Yet in regards to clinical courses, an additional objective lies in transferring also practical abilities, necessary in the lawyers' future professional work ${ }^{69}$.

Moreover, sensitising to the needs of people threatened by social exclusion also remains an essential element of implementation of the clinical program. ${ }^{70}$ The courses which may have the aforesaid educational effects may adopt a form of simulations, workshops or Oxford-style debates. The model of clinical courses is extremely valuable for the purposes of preparing all courses with a group and should be used as an great example of how to work and teach, using methods which involve all group members and allow to memorise by doing, which is better than only by listening. It is encouraging that within the judge traineeship programs the emphasis has been put on active forms of work with the group, in didactic work with future judges and prosecutors. ${ }^{71}$ The methodology of education at such types of traineeship envisages

\footnotetext{
${ }^{68}$ One can indicate e.g.: M. Szeroczyńska, I. Mulak, Jak uczyć prawników dobrej komunikacji z klientem, Warsaw 2015; Ł. Bojarski, B. Namysłowska-Gabrysiak, Symulacja rozpraw sadowych jako metoda edukacyjna. Materiaty do przygotowania i przeprowadzenia symulacji, Warsaw 2008.

${ }^{69}$ See more e.g.: F. Zoll, Jaka szkoła prawa, Warsaw 2004, and the whole charter by: L. Wortham, C. Klein, Ł. Bojarski in: The Legal Clinic. The Idea, Organization, Methodology, Warsaw 2005. The book can be find here: http://www.fupp.org.pl/down/legal clinic.pdf. (Last cited ?).

70 P. Kubiak, $O$ empatii $i$ wypaleniu $w$ pracy studenta kliniki prawa - czyli jak pomagać i się nie przejmować, in: Klinika no. 18(22)2015, p. 9 et seq., as well as A. Świderek: Metodyka zajęć Street Law, znaczenie dla społeczeństwa obywatelskiego i dobre praktyki, in : Klinika no. 13 (17) 2012, p. 3 et seq. ${ }^{71}$ See F. Zoll,. Wprowadzenie do programu aplikacji ogólnej oraz aplikacji sędziowskiej i prokuratorskiej, https://www.kssip.gov.pl/aplikacjelo-aplikacjach/metodyki-nauczania (Last cited 18/05/2017).
} 
case study methods, the simulation of proceedings and main courses (which are intended to be run using the interactive method and implemented in a small group). ${ }^{72}$

Currently, the works on the reform of the Act dedicated to higher education are pending in Poland. They are performed by the Ministry of Science and Higher Education. In the Ministry's view:

"an in-depth revision is required for the system of financing the universities, as well as the manner of managing the universities and the higher educational institutions. It is necessary to internationalise the education, intensify the cooperation between the science and the business, create new paths of academic and didactic career and adjust the number of students for particular fields of study to real needs of the labour market ${ }^{73}$."

The centre of each reform and the main objective shall always be fulfilling the students' needs and transferring the necessary knowledge to them in the course of higher education studies. The experience of these Polish clinical teachers may be used for the purposes of contemplated higher education reforms in Poland as regards, inter alia, the methodology of working with students.

Only the complete preparation and open-mindedness to active methods, as well as new technologies and the modern attitude towards a student-lecturer relationship and the role of a lecturer himself, will allow the full implementation of the

\footnotetext{
72 Ibid.

${ }^{73}$ For more information please see, http://www.nauka.gov.pl/strategia-gowina/ (Last cited 18/05/2017).
} 
reccomendations of the programmes of higher education institutions and enable them to educate in a responsible manner in the future.

While projecting the changes to the higher education sphere, also the technological innovations shall be implemented during the work with the students. It is particularly important with respect to the implementation of law-related courses due to the increasing computerisation of the judicial system. ${ }^{74} \mathrm{~A}$ student has to be prepared to work individually with the courts' computerised system and shall be able to use adequate IT platforms.

Courses in smaller groups undoubtedly facilitate the transfer of knowledge (with good impact on activating ${ }^{75}$ ). They also allow the implementation of the standards of the university legal clinics, for years being undertaken on the basis of the model of a small group - active methods - and substantive support of a mentor.

This method of conducting the courses is increasingly being used also for the implementation of other academic courses (traditionally more non-interactive) and allows the students to have an opportunity of participating in the attractive activities outside of the legal clinic.

\footnotetext{
${ }^{74}$ Regarding the computerization of the judicial system, see further: K. Flaga-Gieruszyńska, J. Gołaczyński, D. Szostek, Informatyzacja postępowania cywilnego, Warsaw 2016; R. Cisek, E-protokót i inne "nowinki" informatyzacji sadownictwa, czyli po co to komu? in: Kwartalnik Naukowy Prawo Mediów Elektronicznych no. 3/2011 p. 5 et seq., K. J. Furman (Kowalska), Przygotowanie do wykonywania zawodu prawnika w świecie zinformatyzowanego wymiaru sprawiedliwości - rozważania na tle działalności europejskich klinik prawa , in: Prawo Mediów Elektronicznych, 2015.

75 B. Niesporek-Szamburska, Metody I formy pracy, online: http://www.fil.us.edu.pl/dok/doktoranckie/dokument3.pdf (Last cited 15/12/2015).
} 
The methodology of clinical education shall constitute the inspiration for planned courses at higher education institutions. Of course, the implementation of its certain achievements, e.g. teaching through the mock court trials or conducting workshops with a group of students, requires not only a qualified lecturer, but also an adequate architectural and technical background (the size of an auditorium, the desks and chairs layout are of importance). These elements shall be taken into account when planning changes of and introducing new classes to the timetable of academic courses of a given university. Undoubtedly, the demand for such backup will generate the change of the way of thinking about the academic sphere.

It is crucial to ensure that academic teachers are able to constantly enhance competences in regards to pedagogy, group work and public appearances.

Persons willing to practise in this profession shall have completed courses in this respect. It would be desirable to introduce such courses as early as during the doctoral studies. The needs as regards the enhancement of teachers' competences are met by one of the projects of the Ministry of Science and Higher Education, aimed at the establishment of models of teachers' education, ${ }^{76}$ the main objectives of which are: "preparing a detailed comparative analysis regarding the systems of teachers' education in selected European countries and recommendations as regards

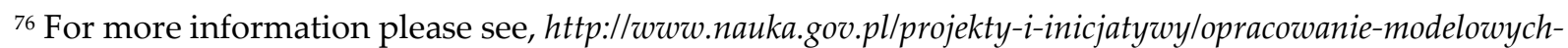
programow-ksztalcenia-nauczycieli-w-ramach-dzialania-3-1-kompetencje-w-szkolnictwie-wyzszym.html (Last cited 18/05/2017).
} 
the changes to the system of teachers' education in Poland, and establishing

models of teachers' education at the higher education institutions." 77

Such high expectations shall be met by the teachers exercising their profession at all educational levels, including the academic stage ${ }^{78}$.

\section{CONCLUSIONS}

A progress in diversity of legal professions is currently being observed in Poland. This can be seen, inter alia, in the possibility of employing the lawyers with three years of experience in providing free-of-charge legal advice in free-of-charge legal assistance points, which results in the fact that the students, acting in the clinics since the second year of their studies, are granted the right to practice the profession of a legal adviser instantly following graduation.

Such a dimension of the progressive deregulation of legal professions means that the legislator has confidence in the quality of legal assistance provided at Polish legal clinics, which use and develop modern education methods and new technical solutions, making it possible to achieve outstanding learning outcomes.

\footnotetext{
77 Ibid.

${ }^{78}$ In the literature, it is pointed out that training is an inseparable element of teacher's professional development. See: G. Kosiba, Doskonalenie zawodowe nauczycieli-kategorie, kompetencje, praktyka, in: Forum Oświatowe, Vol 24, No 2(47) (2012), the short abstarct avalaible on: http://forumoswiatowe.pl/index.php/czasopismo/article/view/17/30 (last cited: 14.07.2018), as well as: Podnoszenie kompetencji nauczycieli kształcenia zawodowego we wspótpracy z przedsiębiorstwami, report by: Instytut Nauk Społeczno-Ekonomicznych sp. z o.o., s. 25 and A. Jastrzębska, Kilka uwag o podnoszeniu kwalifikacji zawodowych nauczycieli, czyli o zawodowym dojrzewaniu, on: http://edurada.pl/artykuly/kilkauwag-o-podnoszeniu-kwalifikacji-zawodowych-nauczycieli-czyli-o-zawodowym-dojrzewaniu (last cited: 14.07 .2018$)$.
} 
It may be concluded that clinical legal education has proved to be a good educational method because lawyers educated in legal clinics haven't many barriers or issues with finding a job, and currently constitutes an answer to the needs of a widely understood market of legal services in Poland, in both the fee-based and freeof-charge sectors. ${ }^{79}$

${ }^{79}$ K. Mamak, W. Górowski, Absolwenci studenckich poradni prawnych cenieni na rynku pracy, 2017. http://karne24.com/dr-gorowski-absolwenci-studenckich-poradni-prawnych-cenieni-rynku-pracy/ (Last cited 03/01/2018). 